\title{
Diamonds of the Night (Démanty noci)
}

Author: Arnošt Lustig

First Published: 1958

Translations: English (Diamonds in the Night, 1962; the new translation Diamonds of the Night, 1977); Spanish (Diamontes de la noche, in: Esperanza, 1963); German (Demanten der Nacht, 1964); Slovak (Diamanty noci, 2010).

Film Adaptation: Démanty noci (the short story Darkness Casts No Shadow; Diamonds of the Night); feature film, screenplay Arnošt Lustig and Jan Němec; film director Jan Němec, premiered the 25th of September, 1964.

About the Author: Arnošt Lustig (1926-2011) was born in Prague into a comfortable middle-class Czech-Jewish family. In 1941 he was expelled from secondary school because he was a Jew. In 1942, his family was sent to the Theresienstadt Ghetto, from where in September 1944, they were deported to Auschwitz-Birkenau. His father was gassed there. Arnošt, his mother, and sister survived. Lustig was taken to Buchenwald and then, in April 1945, he escaped from a train carrying him to the Dachau concentration camp. This experience inspired his short story Darkness Casts No Shadow in the book Diamonds of the Night. He returned to Prague in time to take part in the May Uprising against the Nazi occupation in 1945.

After the war, Lustig became a member of the Communist Party. He studied at the School of Political and Social Sciences in Prague (completing his studies in 1950) and worked as a journalist in newspapers, magazines and at Radio Prague. He reported on the Arab-Israeli War from 1948 to 1949. From 1961 to 1968 Lustig was a scriptwriter for the state Barrandov Film Studio. In June 1967, Lustig and other Czech writers supported Israel in the Six-Day War against Egypt and Syria, and so they came into a conflict with Communist leadership which condemned Israel as an "aggressor". Following the Soviet-led invasion in August 1968, he left Czechoslovakia, first to Israel, and later in 1970, to the United States where he taught, mostly in Washington D.C. at the American University, giving lectures on creative writing, film and literature. After the Velvet Revolution in 1989, he divided his time between Prague and the U. S.

Apart from a few stories, the Holocaust was the subject of Lustig's writing the whole time. His first works were among his best. They included the short stories Night and Hope, and Diamonds of the Night. Lustig's stories often thematised the fate of beautiful Jewish girls or young women in prison camps ( $\rightarrow$ A Prayer for Katerina Horovitzova, The Unloved, Colette, Lovely Green Eyes etc.). It is typical for his later works that the author adapted and expanded his earlier texts, their original introspective and laconic character changing to a contemplative, verbose style. 
Further Important Publications: Noc a naděje (1958, Night and Hope; short stories); Dita Saxová (1962, Dita Saxová; novella); Modlitba pro Kateřinu Horovitzovou (1964, $\rightarrow$ A Prayer for Katerina Horovitzova; novella); $Z$ deníku sedmnáctileté Perly Sch. (1979, From the Diary of Perla Sch., seventeen years old; later under the title Nemilovaná, The Unloved; fictional diary); Colette: Divka z Antverp (1992, Colette: A Girl from Antwerp; novella); Krásné zelené oči (2000, Lovely Green Eyes; novel).

\section{Content and Interpretation}

Diamonds of the Night originally contained nine short stories. In 1966, the new story The Last Day of the Fire, was added. Later Darkness Casts No Shadow, the longest of the stories, was extended, and came out separately as a novella (at first in the English translation, 1977). Since the 1970s and 1980s another story, Early in the Morning, originally published in the collection The Bitter Smell of Almonds (Hořká vưně mandlí) in 1968, was attached. The texts were also gradually expanded with new episodes, reflections of characters as well as narrator's comments. For these reasons they lost their concise laconicity.

These stories thematise the persecution of Jews in Nazi ghettos, concentration camps and also the escape of two Jewish teens from a transport (Darkness Casts No Shadow) or the resistance of the Jews in the Warsaw Uprising in 1943 (The Last Day of the Fire) and in the Prague Uprising in 1945 (The Boy at the Window or Black Lion). Lustig's characters are often children, very young or old people, unheroic "ordinary" figures who find themselves in extraordinary "life or death" situations. For instance, the Warsaw Uprising is depicted through the eyes of two characters, the eighty-yearold Prague Jew Emil Löwy-Cohen as well as his very young grandson Josef nicknamed Chick, who both remain alone in the ruins of their house in the ghetto.

The author uses third person narrative with a lot of dialogue. Mainly in the original versions of the stories, the narrator describes the surroundings, appearance and behaviour of the characters without emotion.

For example, the story Morsel (Sousto), in the English translation as The Lemon, describes a boy in the Lodz Ghetto who extracts his deceased father's golden tooth in order to trade it for a lemon needed urgently by his ill sister. After his father's death, he is forced to accept the role as the family's breadwinner. Therefore, he convinces himself that his father's body is something foreign:

For a short while an insurance agent had lived in the corner shop. But this isn't your father anymore, he told himself, he was only until yesterday. Now there is nothing but a weight and the task of carrying it away, he reminded himself immediately. But I'll think of him only in good ways. And mother and Miriam will think about him as if nothing's happened. (Lustig, 1986, p. 22; italics by A.L.)

Lustig's narration concentrates on his characters' minds at the moment of crisis. It portrays exceptional situations beyond all normal limits where decisions about life and death must be made. The narration uses hints, condensation or description of 
subjective observations of time. The Second Round depicts a boy nicknamed Marquis who only has a few minutes to run up to a wagon, steal a loaf of bread, and return to his starving friends before the Scharführer makes his rounds once again. If he does not make it in time, the patrol will shoot him. The narrator details the boy's inner consciousness during this situation for more than ten pages. He gets the bread, but is followed by the patrol. Therefore he throws the loaf away where it is immediately eaten by other prisoners, and not by his friends. The Scharführer wants to shoot him, however, Marquis's friend named "the little one" rescues him in the last second by jumping between him and the patrol. The story describes the solidarity among friends in the transport, a certain humanity of the German soldier (who in the end saves Marquis), but also the indifference and non-solidarity of the other prisoners who eat the bread intended for Marquis and his friends and who watch apathetically as Marquis is threatened with death.

\section{Main Topics and Problems}

In Czech literature, the theme of the Shoah was increasingly developed only at the end of the 1950s, when the Stalinist system was being dismantled, and later, especially in the 1960s, as Czechoslovak culture underwent great liberalisation. One of the first prosaists to enter the scene in that period was Arnošt Lustig.

Lustig knew the ghetto and the concentration camps from personal experience during the years between 1942 and 1945:

I remember getting off a train in September 1944, and finding myself on a railway platform at Auschwitz-Birkenau. We felt like animals during an eclipse of the sun or forest fire or just before an earthquake. In the space of a few minutes everyone - children up to the age of fifteen, men and women over forty, people who were ill, wore glasses or had grey hair - found themselves in batouses where gas (Zyklon-B) instead of water poured down from the showers. (Haman, 1995, p. 10)

Lustig's stories interweave several autobiographical experiences, such as his escape from the transport in the story Darkness Casts No Shadow (see above) in a fictional way. Nevertheless, his first stories avoid horrible scenes from ghettos or concentration camps. A specific feature of Lustig's writing is the use of a child's point of view of the Holocaust. Arnošt Lustig was the first Czech or Slovak author who applied this narrative device very often. See $\rightarrow$ The Association for the Protection of Animals, $\rightarrow$ The Death of the Beautiful Deer or $\rightarrow$ The Lilies of Erika. Children, both innocent victims of the war and authentic, naive witnesses, have since been used as some of the main symbols of the Holocaust.

Similarly to Jiři Weil and his $\rightarrow$ Life with a Star, the author makes use of an intimate, inner perspective (even though he narrates in the third person) and "coldness" of the narration (understatement). Lustig's protagonists are not traditionally heroic men and women but outsiders, children or old people. Interestingly, the narrator does not equate good only with the Jews (as victims of persecution) nor evil only with the 
German Nazis (as the executors of this). See the short story Michael and the Other Boy with the Dagger describing an encounter between a Jewish and a German boy. Lustig also distinguishes himself by his non-conventional picture of the war and the concentration camps, usually depicted in terms of active resistance against the Nazis. Despite all the bleakness which these people must repeatedly undergo, donning an outer shell just to survive, the majority of them try to maintain basic moral values.

\section{Cited Works}

Haman, A. (1995). Arnošt Lustig. Jinočany: H+H. Holý, J., Sladovníková, Š. (2019). Próza Tma nemá stín a film Démanty noci. World Literature Studies, 28(3), pp. 17-27. Lustig, A. (1986). Diamonds of the Night. Evanston: Northwestern University Press.

\section{Further References}

Bauer, M. (2007). Literatúra je jediná nesmrtelnost' člověka. In: A. Lustig, Odpovede. Bratislava: SNM, Múzeum židovskej kultúry, pp. 41-58. Haman, A. (2001). Arnošt Lustig. In: S. Serafin, ed., Twentieth-Century Eastern European Writers. Detroit: The Gale Group, pp. 233-242. Klima, C. A. (2002). Darkness Casts No Shadow; Diamonds of the Night. In: T. Riggs, ed., Reference Guide to Holocaust Literature. Detroit: St. James Press, pp. 402-403 and 408. Pynsent, R. (2004). Arnošt Lustig. In: E. Sicher, ed., Holocaust Novelists. Detroit: The Gale Group, pp. 220-226. Suchomel, M. (1992). Literatura $z$ času krize. Brno: Atlantis, pp. 21-34. Trucks, R. (1999). A Conversation with Arnošt Lustig. New England Review, 20(14, Spring 1999), pp. 68-77. Vohryzek, J. (1995). Literární kritiky. Praha: Torst, pp. 126-130.

JH 